\title{
Medical student in the family health strategy on the first years of college: perception of graduates
}

\author{
ESTUDANTE DE MEDICINA NA ESTRATÉGIA SAÚDE DA FAMÍLIA EM SÉRIES INICIAIS: \\ PERCEPÇÃO DOS EGRESSOS
}

\author{
ESTUDIANTE DE MEDICINA EN LA ESTRATEGIA SALUD DE LA FAMILIA EN SERIES \\ INICIALES: PERCEPCIÓN DE LOS EGRESOS
}

\section{Maria Paula Ferreira Ricardo', Maria José Sanches Marin², Marcia Aparecida Padovan Otaniª Marina Sanches Marin ${ }^{4}$}

\begin{abstract}
There is a lack of knowledge about the effective value of the experience gained by medical students who participate in the Family Health Strategy (Estratégia Saúde da Família (ESF)) during the early stages of their medical training. This teaching strategy is based on learning by experiencing the problems that exist in real life. This study proposed to understand the value of this teaching strategy from the viewpoint of the students who had participated, after their graduation. The method adopted was a qualitative study conducted through interviews with students who graduated in the years 2009, 2010 and 2011. The data analysis used the hermeneutic dialectic technique as its model. The graduates considered that this experience enabled them to understand the organization and functioning of the health service and the context of the daily life of the users. This experience facilitated the doctor patient relationship, the development of clinical reasoning and the bond with the user. However the students emphasized that a lack of maturity prevented them gaining a higher level of benefit from the experience. Therefore, although the structure of the course is permeated by advances and challenges, it was concluded that this experience contributed to the student's learning of certain essential elements of medical training.
\end{abstract}

\section{DESCRIPTORS}

Family Health

Teaching

Medial Education

\section{RESUMO}

Considerando o desconhecimento do efetivo significado da vivência de estudantes de medicina ao serem inserido Estratégia Saúde da Família (ESF) em séries iniciais do curso por meio de estratégias de ensino baseadas na problematizaçao da realidade, propôs-se a compreender tal inserção na ótica dos egressos. Estudo qualitativo realizado por meio de entrevistas com egressos formados nos anos de 2009, 2010 e 2011. A análise dos dados teve como referência a técnica da hermenêutica-dialética. Os egressos consideram que essa inserção possibilitou o conhecimento da organização e funcionamento do serviço de saúde e do contexto de vida dos usuários, facilitou a relação médico paciente, o desenvolvimento do raciocínio clínico e o vínculo. Destacam, no entanto, que a imaturidade do estudante impede maior aproveitamento da vivência. Embora essa trajetória esteja permeada por avanços e desafios, conclui-se que ela se mostra capaz de sedimentar elementos imprescindíveis à formação médica.

\section{RESUMEN}

Considerando el desconocimiento del efectivo significado de la vivencia de estudiantes de medicina al ser inserido Estrategia Salud de la Familia (ESF) en series iniciales del curso por medio de estrategias de enseñanza basadas en la problematización de la realidad, se propuso a comprender tal inserción en la óptica de los egresos. Estudio cualitativo realizado por medio de entrevistas con egresos formados en los años de 2009, 2010 y 2011. El análisis de los datos tuvo como referencia la técnica de la hermenéutica-dialéctica. Los egresos consideran que esa inserción posibilitó el conocimiento de la organización y funcionamiento del servicio de salud y del contexto de vida de los usuarios, facilitó la relación médico paciente, el desarrollo del raciocinio clínico y el vínculo. Destacan, aunque, que la inmadurez del estudiante impide mayor aprovechamiento de la vivencia. Sin embargo esa trayectoria esté permeada por avances y desafíos, se concluye que ella se muestra capaz de sedimentar elementos imprescindibles a la formación médica.

\author{
DESCRITORES \\ Saúde da família \\ Ensino \\ Educação médica
}

\author{
DESCRIPTORES \\ Salud de la família \\ Enseñanza \\ Educación médica
}

\footnotetext{
${ }^{1}$ Teacher of Nursing Course of Marilia Medical School, Marilia, Brazil. ${ }^{2}$ Medical Course of Marilia Medical School, Marilia, Brazil. ${ }^{3}$ Teacher of Nursing Course of Marilia Medical School, Marilia, Brazil. ${ }^{4}$ Medical School student at the Catholic University of Paraná, Curitiba, Brazil. 


\section{INTRODUCTION}

The training of health professionals that is aimed at their acquiring a comprehensive and humane vision of the process of health and illness of individuals, families and communities, has been strongly emphasized in medical training in Brazil in recent decades. This was partly a reflection of the global trend to improving the health professional's skill profile, and also, more specifically, to the current National Health Policy that was developed based on Brazil's constitutional reform approved in $1988^{(1)}$.

The creation of the National Health System (Sistema Único de Saúde, known as SUS) required profound changes in the ways of thinking and acting of those involved. This was especially true for health professionals, who are the main players promoting these changes, and who had the responsibility to develop initiatives and implement a new rationale for care in health services. As a result a new model of care, the Family Health Strategy (ESF), was implemented nationwide with the primary goal of strengthening primary health care, through an interdisciplinary approach applied within a given local area. A new set of National Curriculum Guidelines (DCN) for medical training was developed to train health professionals in accordance with this perspective. The objective was to provide professionals with a good general level of training, with a humanistic, critical and reflective vision, preparing them to work in accordance with the SUS principles and guidelines ${ }^{(2)}$.

In the recent proposals for new curriculum guidelines for medical courses, these principles have been reaffirmed, and specific measures to strengthen them have been indicated, through the requirement that $35 \%$ of the student's workload during his period of residency be dedicated to the area of primary health care. Furthermore, the guidelines recommended the creation of learning opportunities, in a cross-cutting manner, with the fields of humanities and social sciences, as well as the participation of students in the health service network from the very beginning of their course ${ }^{(3)}$.

Despite such guidance, it can be said that, Brazilian medical schools are still not organized in a way that ensures an emphasis on the ESF(4). A study conducted with medical students indicated that early participation in ESF units presented problems, both in terms of structure and with respect to the integration of teaching with service and community that made the situation inappropriate to the learning process ${ }^{(5)}$.

For more than a decade, a certain faculty of medicine located in the state of São Paulo, Brazil, has made progress in meeting the SUS and DCN principles and guidelines. The curriculum has been organized by skills and active methods have been adopted in the teaching and learning process. A partnership with the municipal health services led to the participation of teachers and students in the local health services. As a result they carried out the major- ity of the teaching activities of the first, second and fourth years of study at the ESF(6). This initiative has been supported by projects linked to the Ministry of Health, namely, Pro-Health and Education for Health Services Work Program (PET-Health Services). These programs contribute to strengthening the integration of teaching-services with an emphasis on educational actions to promote health.

Students participate in the ESF from the first year of the course in an activity called the Professional Practice Unit (Unidade de Prática Profissional (UPP). In these units they participate in the team work process in relation to individual and collective care, and to the management of health services, by accompanying the families of the area covered and the different activities performed by the team. The experiences of students in this situation were problematized and, based on a review of various sources, we defined intervention strategies to be implemented jointly with the health service team.

By doing this the intention was to align the professional training to the SUS principles and guidelines, which emphasize health promotion through vigilance. However, one cannot deny that this runs contrary to the approach to care that focuses on biological aspects, that is, the main complaint and serving the user's need. This approach is strongly rooted in the imagination of students, health professionals, and community service managers, and hinders the transformation of professional practice.

Although one can acknowledge the potential of the reorganization of the curriculum currently under development, in practice difficulties in its implementation can be observed, and there is no information on the effective significance of this experience on the doctor's performance in the many different activities he carries out. Faced with this situation, the objective of this study is to understand the significance of the participation of students in the ESF daily work practice, as from the first year of the medical course, from the perspective of graduates of a medical school.

\section{METHODOLOGY}

This was a qualitative study involving graduates from a medical training course of a faculty of medicine located in a medium-sized city in the state of São Paulo, Brazil. This institution was established by the state of São Paulo and has an annual intake of 40 students in the course for nursing and 80 in the course for medicine. Besides these two courses, the institution also manages a hospital complex and day clinics in various specialties.

These facilities constitute the teaching and learning environment for the nursing and medical students and the institution also has a partnership with the Municipal Department of Health, in order to diversify these environments and enable the formation of generalists with an emphasis on primary care, as proposed in the National 
Curriculum Guidelines. Of the 32 ESFs in the municipality, 20 have been made available to the nursing and medical students enrolled at Fanema.

The curricular structure of the medical course includes an UPP and a Systematized Educational Unit (Unidade Educacional Sistematizada (UES). It seeks to promote the development of cognitive, affective and psychomotor resources that can be mobilized and integrated to perform tasks that are aimed at identifying the health needs of individuals, families and communities.

The UES follows the methodology of Problem Based Learning (Aprendizagem Baseada em Problemas ( $A B L)$ ) and seeks to create opportunities for the further elaboration of cognitive processes related to the problem situations presented in different learning scenarios. Furthermore, it takes a broader view of the health needs of the health services' users, emphasizing the health-disease process, validating experiences and promoting meaningful learning.

In the real-life scenario (UPP), the health needs of individuals and their families are problematized, the health problem is formulated and a care plan is prepared. These practices alternate with group discussion activities, in which each pair of students chooses one or more situations to be presented and, based on reading and clarifications, problematizes these situations. Once the knowledge gaps have been identified, the study questions are prepared, and the students seek the information to answer the questions set. In a group setting the information found is shared and a new summary prepared. Finally, to complete the cycle, there is an oral evaluation (self-evaluation, evaluations of the group, the teachers and the cycle).

The participants in the study were medical school graduates who completed the course in the years 2009, 2010 and 2011, numbering 76, 78 and 83 participants, respectively. Five graduates of each class underwent recorded interviews, based on the following guiding question: "What is the significance of the student's participation in professional health service practices in the early years of his medical training?" The interviews were conducted in November and December 2013 and had an average duration of 20 minutes.

The hermeneutic dialectic methodology was used for the treatment and analysis of the data generated by the narratives of the subjects, since we sought to understand the meanings underlying the narratives, through understanding the meaning of the facts which formed the dynamics of experienced process. The hermeneutic dialectic analysis comprises the following steps: comprehensive reading of the context in which the data is generated, creation of analytical frameworks in which one seeks ideas that underlie the texts, identifying broader meanings, proceeding in a synthesis of movement through the construction of possible meanings ${ }^{(7)}$. The research proposal was submitted to the Ethics Committee for Human Re- search. Opinion number: 359.585 de 14/08/2013, CAAE: 7992413.0.0000.5413. Participants were informed about the study's purpose and, when they agreed to participate, they signed a declaration of free and informed consent.

\section{RESULTS AND DISCUSSION}

The graduates interviewed were in the range of 25-32 years old, eight of them were still completing their period of residency, while the remainder had concluded the whole course. It is noteworthy, however, that only one graduate is now working in the ESF and one other, specialized in psychiatry, is working in the Family Health Support Center(NASF). The other graduates pursued many different specialties such as: radiology, pediatrics, nuclear medicine, occupational medicine, pulmonology, cardiology, infectious diseases, general surgery, dermatology and otolaryngology.

Even so, in the words of these graduates, it appears that this form of curriculum organization, which puts the first-year student in ongoing contact with the community, enabled them to appreciate and absorb soft technologies as central to health care. This is a position, advocated as essential to the production of care and that, therefore, should permeate the training course in the various situations of health care $^{(8)}$.

As noted in the following quote, their participation in the Family Health Strategy from the first year of the course helps to provide knowledge about the functioning of the health services.

I found it very important to understand how the Family Health Program functions. What the function of each member of the unit is, the issue of team meetings and why they were important, and because the community agents were inserted into the reality of these people, they knew them up close, because they lived in this neighborhood. E13

In order to train a student to be a critical and reflective professional, capable of transforming the reality of the activity, as proposed in the curriculum guidelines, an understanding of the context in which he is inserted and the functioning of the health services is an important first step. Furthermore, this initiative introduces the premise of the diversification of the work environment, meeting the need to dehospitalize medical training. Although the hospitalization model has remained dominant for many years, it does not address today's social needs or the SUS guidelines. Besides learning about the operation of the health service and the organization of the health service team, the graduates indicated that their participation in the FHS allowed them to know about the context of people's lives, which was often completely different from way that the students themselves lived. The understanding of different realities includes the way of living in the face of different social conditions, beliefs and values.
Medical student in the family health strategy on the first years of college: perception of graduates Ricardo MPF, Marin MJS, Otani MAP, Marin MS 
For me, at first, it was a bit of a shock ... because it was a reality very different from mine. I left one world and I began to participate in another one with completely different people, different difficulties, different problems (...). I think I would not have another way of learning so much if it were not this way. (E2)

From this perspective it was emphasized that the abovementioned participation allowed a broad view of the healthillness process, involving the biopsychosocial aspects.

We have a vision that is very much on the social side as well, of the psychic side of the patient. Then we start to consider the medication, why to take it, why not to take it, why couldn't he follow the diet, what were the health needs that were failing. In this way, we can get an overview of the patient and not only be focused on the illness. I think it was a much more complete history of the case, this biopsychosocial part, not just the biological. (E15)

One can identify, therefore, a move towards the principle of completeness, which means taking a new stance to health care, that is, proposing new solutions to meet the needs of individuals, families and the community and meeting demands that were hidden or neglected for a long time by a fragmented and biological model ${ }^{(9)}$.

The tasks proposed for the first and second years of the course, with a view to a broader approach, performed through making home visits, required the student to establish a bond since he would accompany families for a period of two years. In this situation, one can see that the student takes on a different position in relation to other contexts of care, in which the user, because he is outside of his own environment and, in a majority of cases, suffering from an illness which makes him vulnerable, ends up by submitting passively.

(...) we studied how to talk to the patient, how to get in touch with him, visiting his house, seeing in the patient's home how he is, I think that the big difference was the creation of a bond, making it easy to empathize with the patient and the opportunity to visit him at his house, which is his environment. (E14)

In relation to the house visits undertaken by the students in the early years of the course, a study carried out at the same institution with a view to ascertaining the views of users, revealed that although the vision of care focused on the illness, they indicated a set of attributes that went beyond the care of a biological body, including the importance of interpersonal relations in the context of health care, the need for listening, for care, for guidance and for being concerned about providing answers and referrals for the identified needs ${ }^{(10)}$.

(...) I was able learn very well how we would take action when faced with that patient in his own reality. It's totally different when you meet a patient in his house, to be received in his house than when you meet him interned, in the hospital. (E13)

The points raised by the graduates regarding the doctor-patient relationship, and the ability to communicate and establish a bond, are aligned to the guidelines of the National Humanization Policy, which is the central reference when proposing changes in the model of health care. This policy, established by the Brazilian Ministry of Health, encourages the development of health service practices that have a greater appreciation of the different subjects involved in the production process of health care and, therefore, highlights as essential the appreciation of listening, the bond and affection in the practices of health service professionals ${ }^{(11)}$.

I think it's important....most important, this question of looking at the patient and not the disease. Looking at him within the context in which he lives (E13).

The importance of the humanization of health care means it is essential to have contributions from the social sciences and humanities in the development of the skills that students must acquire to exercise the profession ${ }^{(12)}$.

Understanding the communication process and developing communication skills are fundamental for all health service professionals. However, currently, the degree of recognition given to the impact of communication in health services has been less than it should be.

In the process of communication among people with different levels of education and knowledge, one of the most difficult tasks for the health team is to discard its own position and force itself to understand, which of course is also an enriching experience ${ }^{(13)}$. To achieve this asymmetry it is necessary to understand the differences in worldviews and ways of life of people in different contexts.

Although, recently, this aspect has been emphasized by the national health policy, we must take into account that the creation of policies and strategies are not measures that can generate change just by their implementation; they guide practice and should serve as a source of learning for new experiences ${ }^{(14)}$.

The humanization of health care and, more specifically, effective interpersonal communication, are not innate and will only be established if they are practiced and supported in everyday actions, fed by reproduction among health professionals, either by academic training or by example, in practice $^{(15)}$.

A study carried out with students from six Brazilian medical schools, also identified the doctor patient relationship as a positive aspect gained from participation in the FHS, as well as indicating aspects that related to the values and philosophy of the strategy $\mathrm{y}^{(5)}$.

The testimony below portrays the relevance of a teaching strategy in which the student has the opportunity to exercise and reflect upon his actions in order to learn more appropriate ways of interpersonal behavior and relations.

... this contact with health service practices from the first year of college, allows the student to take a ... a vision 
of responsibility and ethics which is very significant, right from the beginning of college. E5.

So one understands that health care should be discussed together with ethics, with the values of responsibility and integrity. You need to feel, experience the situation to act with clarity, respecting the principles of charity, autonomy and justice ${ }^{(16)}$.

The scientific and technological progress of recent years has brought great advances in the solution of health problems. However, this has also resulted in the increasing specialization and segmentation of health care. This has led to the prioritization of techniques and the impoverishment of interpersonal relations and the communication process. Furthermore, much of the knowledge and techniques currently being recommended will not still be in use in the near future. Therefore, there is a need to use methods and strategies that value self-learning and a critical view of the theoretical and practical knowledge and that encourage listening and meeting the demands of individuals, families and communities ${ }^{(17)}$.

The graduates' testimonies also revealed that, while they were students in the first and second years, they could have made greater use of their practical experience in the family health units. They credited this to their low level of maturity at the time which hindered them from fully grasping the meaning of these experiences.

Ah! It seems like I'm a community agent, it seems so ... it
seems that l'm good for nothing, I'm just here playing a
game'. But I think it's important to know what a community
agent is. To know exactly what a community agent does. (E1)

We arrive there (in the family health unit) thinking that there's no point 'Ah! I'm going to be a doctor and I don't need this'. After you graduate, after a year of graduation you see that it makes a big difference. E2

When you start medical school, students have different expectations in relation to professional practice, and, each one, depending on his life history, beliefs, personal characteristics and attitude to reality, encounters a different degree of difficulty in relation to his adaptation to the course, maturing and learning to be a doctor in the final years of graduation ${ }^{(18)}$.

\section{Many times we went there.... I think that everyone's insecure in the beginning because you don't know what to do right ... you get there, talk to people, suddenly you are invading someone's space, getting in the way of what the person is doing, but as time goes on, you end up creating a bond, they like this pro- cess, people like this contact with ... and they see it as a con- tact with health itself, an interest in quality of life, in health. (E7)}

In the fragments of testimony above one can deduce that when they were confronted with professional practice in the early years of the course they could not yet see clearly the point of being there, which for them was different from what they thought was the role of the doctor.
The differences between what is envisaged and what is understood lead to the need to act in a preventive manner ${ }^{(15)}$, as was also proposed by the graduates themselves.

"One has to make it very clear to students from the moment they arrive, as to how they can make a difference despite not yet having medical training. Sometimes we get there very early, at times it seems like we (....)".

In relation to this difficulty expressed by the students, although it was not suggested by them, it is possible that a greater degree of preparation through the simulation of professional practice before venturing into the user's homes and being confronted with the difference could be a way to soften the impact. The simulation of the situation would give the student the opportunity to face new situations in a more protected environment. Even so, it must be stressed that nothing compares with the complexity imposed in confrontation with reality, because in it are expressed the conditions of the life of the person, family and the community, as well as the form of management and organization of health services in its multiple dimensions. Also relevant in this context, is the integration between teaching and health service, since the participation in fact occurs.

\section{FINAL COMMENTS}

Even though this trajectory is permeated by advances, challenges and difficulties it was possible to absorb elements which are essential to medical training, especially with regard to the relations with users through establishing a bond, proper communication, as well as recognizing that they live in "different worlds", leaving them to adopt behaviors consistent with each reality, involving the totality of the potential and the needs of individuals and families.

It is evident that the home visit in the early years of the course requires that a student develop communication skills, respect for differences and effective responsibility in order to be accepted by the families and, in this way, develop his role.

In this regard, it is important to note that, even when working in different specialties, there are relevant aspects of this participation that form the base for the current practices they are performing. It must be emphasized that only one of the graduates is currently working in the ESF, which is an aspect that should be questioned, given that governmental efforts have been used in order to strengthen the training of professionals to work in primary health care.

It can be affirmed, therefore, that the ESF constitutes an important environment for teaching and learning for medical students in the early years of the course. As a result, it is worth noting that the guidelines for the training of doctors, issued in 2014, reinforced this perspective, and recommended that the participation of students in primary health care be expanded, including during the final years of the course.
Medical student in the family health strategy on the first

years of college: perception of graduates

Ricardo MPF, Marin MJS, Otani MAP,

Marin MS 


\section{REFERENCES}

1. Brasil. Constituição da República Federativa do Brasil de 1988 [Internet]. Brasília: Senado; 1988. [cited 2010 mar 10]. Available from: http://www.planalto.gov.br/ccivil_03/constituicao/ constitui\%C3\%A7ao.htm

2. Brasil. Ministério da Educação. Conselho Nacional de Educação. Câmara de Educação Superior. Resolução n. 4, CNE/CES de 7 de novembro de 2001 [Internet]. Institui diretrizes curriculares nacionais do curso de graduação em medicina. Diário Oficial da União, Brasília, 9 nov. 2001. Seção 1, p. 38. [cited 2010 mar. 10]. Available from: http://portal.mec.gov.br/cne/ arquivos/pedf/ CES04.pdf

3. Brasil. Lei no 12.871 , de 22 de outubro de 2013. Institui o Programa Mais Médicos, altera as Leis no 8.745 , de 9 de dezembro de 1993, e no 6.932, de 7 de julho de 1981, e dá outras providências. Diário Oficial da União. Brasília , 23 out.2013; Seção 1

4. Freeman J, Kelly P, Blasco PG. Attitudes about Family Medicine among Brazilian medical students. Mundo Saúde. 2010;34(3):336-40.

5. Costa JRB, Romano VF, Costa RR, Vitorino, RR, Alves, LA, Gomes, AP, Siqueira-Batista, R. Formação médica na estratégia de saúde da família: percepções discentes. Rev Bras Educ Med.2012;36(3):387-400.

6. Faculdade de Medicina de Marília. Necessidades de saúde: 1 ạ e 2a série - Cursos de Medicina e Enfermagem. Marília; 2010.

7. Minayo MCS. O desafio do conhecimento: pesquisa qualitativa em saúde. São Paulo: Hucitec; 2010.

8. Feuerwerker LCM. Médicos para o SUS: gestão do trabalho e da educação na saúde no olho do furacão! Interface Comun Saúde Educ. 2013;17(47):929-30.

9. Araújo D, Miranda MCG, Brase SL. Formação de profissionais de saúde na perspectiva da integralidade. Rev Baiana Saúde Pública. 2007;31 Supl 1:20-31.
10. Marin MJS, Gomes R, Siqueira Júnior AC, Nunes, CRR, Cardoso, CP, Otani, MP, Moravcik, MY. O sentido da visita domiciliária realizada por estudantes de medicina e enfermagem: um estudo qualitativo com usuários de unidades de saúde da família. Ciênc Saúde Coletiva. 2011;16(11):4357-65.

11. Brasil. Ministério da Saúde. Política Nacional de humanização da Assistência Hospitalar [Internet]. 2004. [cited 2013 set. 10]. Available from: http://bvsms.saude.gov.br/php/level.php?lang=pt \&component $=44 \&$ item $=104$

12. Macias Llanes ME. Ciencias sociales y humanísticas en la formación médica. Rev Hum Med. 2011;11(1):18-44.

13. Campos FE, Brenelli SL, Lobo LC, Haddad, AE. O SUS como escola: a responsabilidade social com a atenção à saúde da população e com a aprendizagem dos futuros profissionais de saúde. Rev Bras Educ Med. 2009;33(4):513-4.

14. Deslandes SF, Mitre RMA. Processo comunicativo e humanização em saúde. Interface Comun Saúde Educ. 2009;13 Supl. 1:641-9.

15. Puggina ACG, Silva MJP. Ética no cuidado e nas relações: premissas para um cuidar mais humano. REME Rev Min Enferm. 2009;13(4):599-605.

16. Campos FE, Belisário AS. O programa de saúde da família e os desafios para a formação profissional e a educação continuada. Interface Comun Saúde Educ. 2001;5(9):133-42.

17. Fiedler PT. Avaliação da qualidade de vida do estudante de medicina e da influência exercida pela formação acadêmica [tese de doutorado]. São Paulo: Faculdade de Medicina da Universidade de São Paulo; 2008. 308 f.

18. Barreto MAM, Reis CN, Miranda IB, et al. Ser médico: o imaginário coletivo de estudantes de medicina acerca da profissão de médico [Internet]. Cad UniFOA. 2009;4(11):73-9. [cited 2013 set. 10]. Available from: http://web.unifoa.edu. br/cadernos/edicao/11/73.pdf 